The Journal of Public Space

2017 | Vol. 2 n. 2

\title{
Urban visions for the architectural project of public space
} Miquel Martí Casanovas, Estanislau Roca

Universitat Politècnica de Catalunya, Spain

Escola Tècnica Superior d'Arquitectura in Barcelona

miquel.marti@upc.edu | estanislao.roca@upc.edu

\begin{abstract}
Public spaces should be places that support an intense civic life. They have been so throughout history, even if in each culture and historical period they have taken very different shapes and followed different design principles. Nevertheless, during the $X X$ century, the Modern Movement faced some difficulties in dealing with public spaces. Too many times the zoning approach opposed the complexity, mix of uses and intensity required by lively public spaces, where social encounters and knowledge exchanges are made possible. In the XXI century, public spaces regained a major role in city projects and urban strategies all over the world. Their appearance was enriched by new forms. Besides the traditional squares, parks and promenades of compact cities, new metropolitan open spaces and collective places related to transport network nodes emerged. This paper focuses on the urban design of such contemporary collective places. Based on an overview of the historical evolution of public spaces, we identify some design principles (from the overlap of scales to acupuncture strategies, through to the complexity of relations between urban architectures) necessary to ensure that metropolitan nodes emerge as places full of urbanity rather than as deserted non places.
\end{abstract}

Keywords: urban design, collective places, metropolitan nodes, urban complexity, urbanity.

\section{To cite this article:}

Martí, M., Roca, E. (2017). Urban visions for the architectural project of public space. The Journal of Public Space, 2(2), 13-26. DOI: 10.5204/jps.v2i2.89

This article has been peer-reviewed and accepted for publication in The Journal of Public Space.

Please see the Editorial Policies under the 'About' section of the journal website for further information.

This work is licensed under a Creative Commons Attribution - Non Commercial 4.0 International License - https://creativecommons.org/licenses/by-nc/4.0/ 


\section{Urbanism and lively public spaces}

We think you've all seen the movie Smoke, starring Harvey Keitel. It is the story of a man who has a cigar shop in Brooklyn. Every day he takes a picture of the same place and collects them. One day whilst reviewing them, he realises that this space, a simple crossroad, whilst seemingly remaining the same, is also subject to constant change, hour by hour and day by day. We can also say that space is built by people. This is also clear, for instance, in the difference between Piazza Ariostea in Ferrara on a normal day and during the celebration of the world's oldest Palio at the end of May.
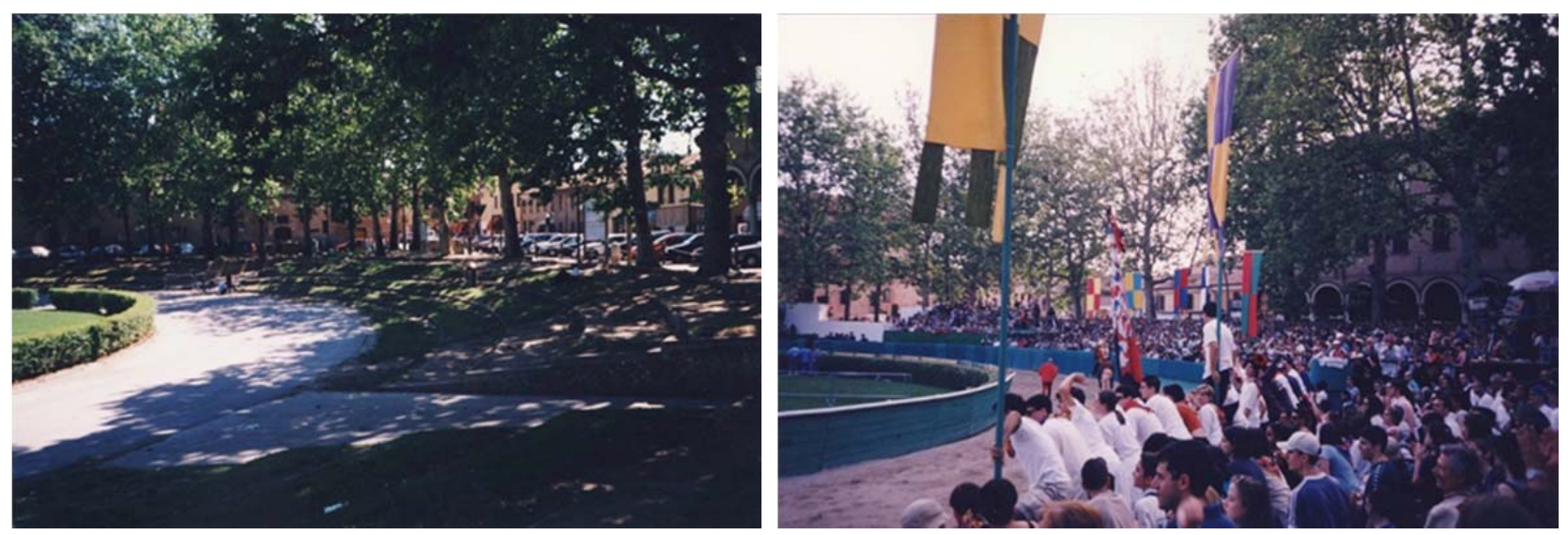

Figure I. Piazza Ariostea on a normal day and during the Palio, Ferrara (photos by authors).

In that sense, the anthropologist Manuel Delgado argues that "in urban spaces which have been architecturally designed in their entirety, sometimes it seems as if sociability has not always been considered. It is as if the project designed on paper or in models was not calculated to support the weight of life which will unfold there. Within the designed space there are no presences, which implies that neither are there absences. Otherwise, the real urban space -not conceived- knows the innumerable heterogeneity of actions and actors...".

We wish to start this paper by reminding ourselves that enhancing sociability is the main aim of urban design for public spaces and thus the focus of our research. Since the beginning of the year 2000, our research within the Department of Urbanism at the Polytechnic University of Catalonia has been oriented towards studying the transformation of public space in different cultural contexts, beginning with the European context. A Doctoral course entitled Public space: experiences, projects and management collects the ongoing outcomes of this line of research. We are interested in how urban, architectural or landscape design can produce or restore urbanity in the city, that is to strengthen urban and social relationships within the public realm. Urban and social relations are in fact closely related, as the two faces of the city, in a long term vis-à-vis between urbs and civitas.

In this research on public space we have considered several phenomena over recent decades (Roca and Martí, 20I3). Among them:

- $\quad$ the implementation of comprehensive policies to improve public space in many compact inner cities around Europe. Policies that since the eighties of the $X X$ century have been overcoming the reductive functional approach to public space (transportation roads, civic centres, green parks...) to introduce more integrated designs. Policies that have developed the formal quality of streetscapes as well as general visions of public space networks. Increasing concerns for sustainable mobility

| 4 | The Journal of Public Space, 2(2), 2017 | ISSN 2206-9658

(C) Queensland University of Technology 
have directed these policies to aim for a friendly city (that is in many cases a walkable and cyclable city) for everybody, thereby considering the different kinds of publics sharing the urban space.

- the transformation of large metropolitan open spaces into new potential public spaces for the regional city. Spaces that can play a new role as structural elements of the metropolis. Spaces that generate new composite landscapes in which natural features, infrastructures or cultural heritage elements are combined. Spaces that seek to enhance and balance new uses, mainly those serving an ecological function, such as various agricultural uses and leisure activities.

- $\quad$ the configuration of metropolitan nodes as collective places. Squares and facilities in central cities constitute metropolitan nodes too, but new kinds of nodes are emerging as social spaces in regional cities. They are nodes related to mobility networks or to systems of leisure and shopping centres. In such nodes, two factors are important to constitute them as collective spaces rather than non-places. Firstly, the governance of regional networks and their integrated conception are key in order to produce places with intense and mixed uses. Secondly, the urban design project is crucial in enabling the architectural and social relationships that produce a collective space. Particularly, the relationships between different levels of the city (for instance the underground levels with the city level or various skywalk levels) and the articulation between outdoor/indoor or public/private spaces are all important issues to be tackled by urban design.

The current research contribution is focused on the last question: how urban design can contribute to generating rich collective places in contemporary metropolitan nodes. We propose a reflection on some guidelines, based on a historical overview of the relationship between architecture and public space.

\section{Urban design of public spaces over time}

Implicitly, the characteristics of any public space have much to do with its historical timeline, but its construction does not always coincide with a single historical period. Over time, streets, squares, parks... develop in one way or another, layer upon layer. Therefore, the time or event that has generated, ordered or reformed them deserves special attention.

The eastern city employs simple geometry as the supporting principle behind the make up of the regular grid. While in Egypt and the East, the centre of the grid had the temple and/or the royal palace, in Greek and Roman cities we already find the Agora and the Forum Square on centre stage (the latter is usually defined by the intersection of two main streets, the cardo maximus and decumanus).

Both the agora and the forum are enclosed by a wall, in order to define their scope and to differentiate amorphous spaces without a specific destination. The agora was a limited space for public buildings. It included a large covered porch, the Stoa, which was the meeting place of citizens. The agora thus becomes the democratic expression of Greek life. It was intended for public life, different from other spaces dedicated to the gods and priests: the Acropolis. I like that in the Acropolis of Athens we can see how all architecture is simple, Euclidean, there are no parallel lines between the different buildings, creating a large spatial tension. This can be a great lesson in modernity for some contemporary metropolitan nodes. 


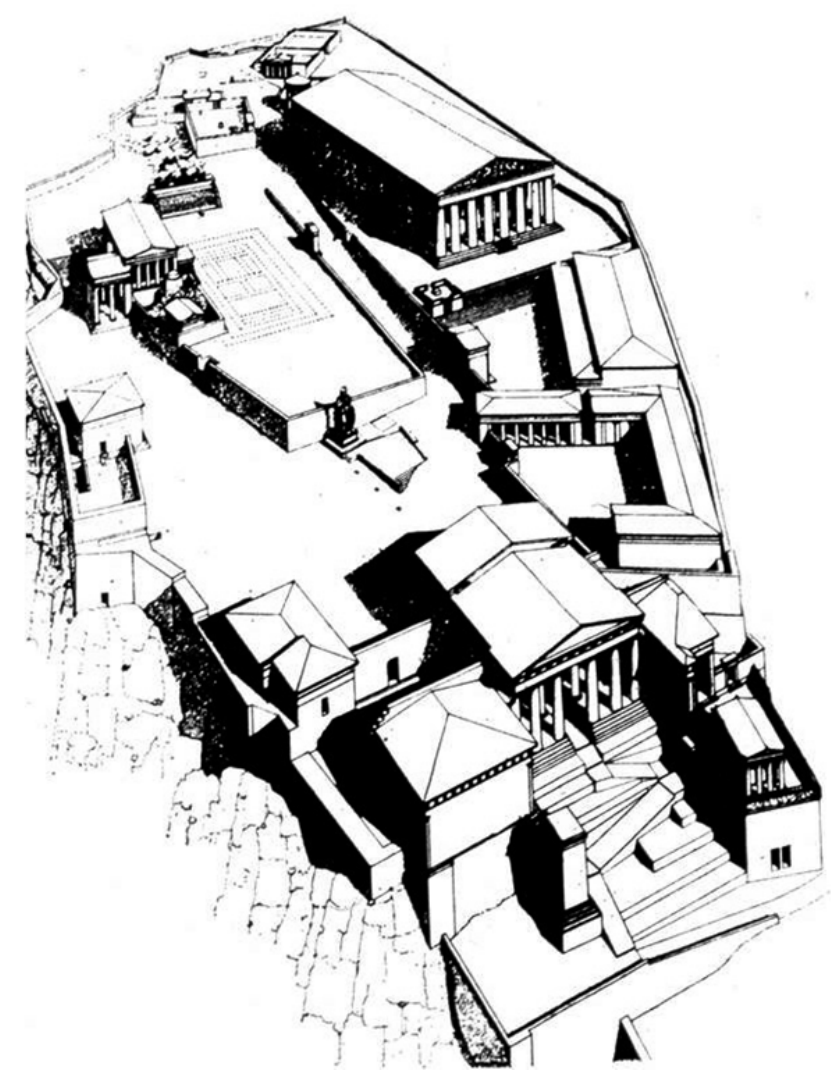

Figure 2. The Acropolis, Athens, drawn by Ludovico Quaroni.

The Roman forum, despite being a public place like the agora, was more multifunctional: business, justice and religion all shared this space. It was a rectangular space, often of gigantic dimensions, responding to a general typology of the Roman city. There was a large porch (the portico) which marked the great plaza or central open space, and a cryptoporticus coinciding with the buildings themselves which housed various offices. The large porch is characterised by a modular treatment in its construction, it regulates the perimeter of the inner space and absorbs connections to outer space.

In the medieval city, the streets were made by the houses. They arose as spaces not occupied by buildings. They were not designed and were irregular in their alignments and widths. They were often very narrow spaces with small expansions or contractions. The city had few open spaces. Public open spaces disappeared. The square was no longer as it had been before, the social meeting place. Public life in a broad sense was not celebrated in a single open space. It was more related to privacy and the street was its public backdrop. And streets were the outcome of the overlaying of a set of interventions, building after building.

The various forms of medieval squares were very diverse. Most were irregular, like streets, and arose from the intersection of two major roads, the widening of the main street in the city or the opening of compact urban fabric. The Piazza del Campo in Siena and the Piazza della Signoria in Florence are good examples. 


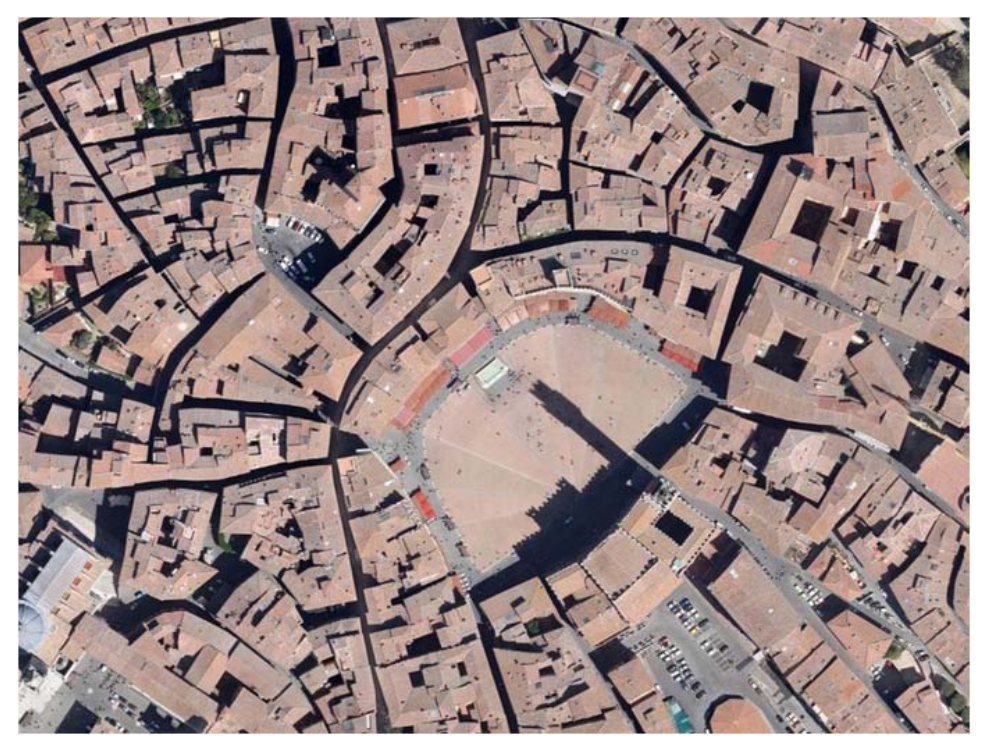

Figure 3. Piazza del Campo, Siena (from Google).

In the overall view of the city it is possible to see the character of the different buildings. The skyline view provided a true reflection of the functions that were produced. There was a clear distinction between the public and private buildings in terms of their size, scale and the architectural treatment of their details. The spires or towers of a church or cathedral and the defence towers all stood out from the skyline. Institutional buildings were usually grouped, creating significant areas of the city. Thus, the skyline was formed by balancing rhythmic accents and modulations. It was a highly expressive profile, which stressed the primacy of spiritual aspirations.

Main squares were placed to accommodate markets and in many Spanish cities their role became even greater during the reign of Fernando and Isabel, while town halls were built under the impulse of the Ordinances of 1480 set by the Cortes of Toledo.

In the Renaissance, palaces and houses were given a geometric order. The use of perspective, the geometric configuration of the perimeter and the enclosure of space were key design devices. The Piazza del Campidoglio, by Michelangelo, is a master example of a square in which all elements are carefully thought out and organised. The Renaissance Square was not, however, a place of intense civic life as it was in the times of the Romans and the Greeks. Concurrently, the streets provided access to buildings, maintaining direct links with major regional roads and facilitating mobility between different parts of the city. Moreover, the concept of straight streets designed as an ensemble was introduced in the Renaissance. Rome is the paradigmatic example of the Renaissance city, while Paris is a prime example of a mid-nineteenth century city. The raw Baroque principles of the straight line, the monumental perspective, uniformity and, sometimes, the surprise effect can be clearly seen in Rome. St. Peter's square was much more spectacular before the construction of Via della Conciliazione that would connect it with Sant'Angelo as part of the Borgo Nuovo reform. Figurative regulations and a general system for the city's street network were also introduced in the Baroque period. 


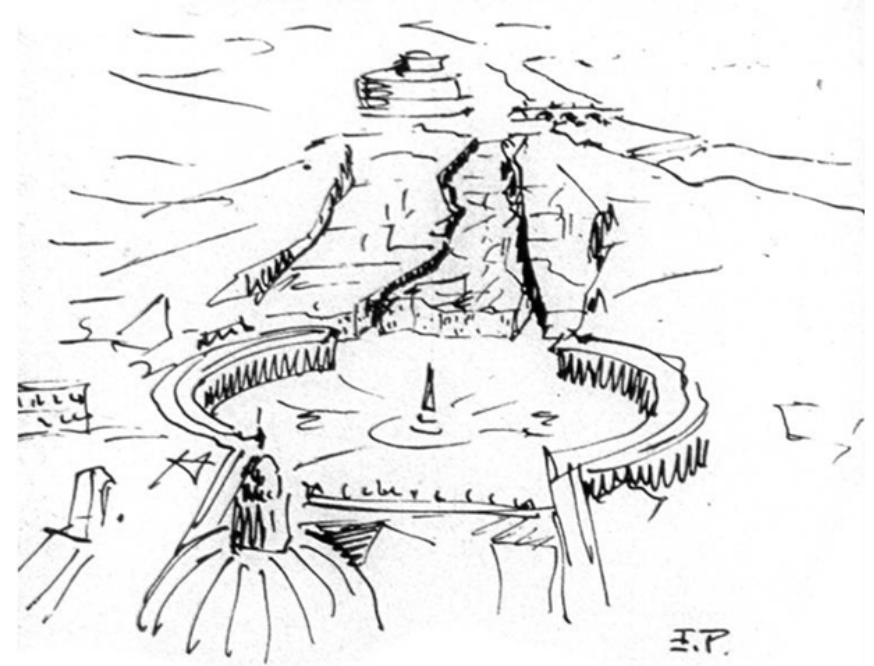

Figure 4. Piazza di San Pietro and the Borgo Nuovo, Rome (archives DUOT).

Another clear example of the tradition of Baroque urban design is a sequence of three squares in Nancy: place Stanislas, place de la Carrière and place de l'Hémicycle. Together they produce a subtle combination of axes and symmetries creating one of the most singular monumental ensembles in the history of urbanism.

But Paris is also a prime illustration of Baroque design. A couple of good examples are Place Royale or Place des Vosges and Louis Le Grand or Place Vendôme. In the case of Place Vendôme, the Duc de Vendôme commissioned Mansard, the most famous architect of the time, to design the facade of a new square in the Marais in Paris. What mattered was the facade,for what was behind it did not matter so much. It was a real-estate transaction. This often happened in the Baroque period and we can see examples of it in many other places such as Barcelona's Plaza Reial or Madrid's Plaza Mayor.
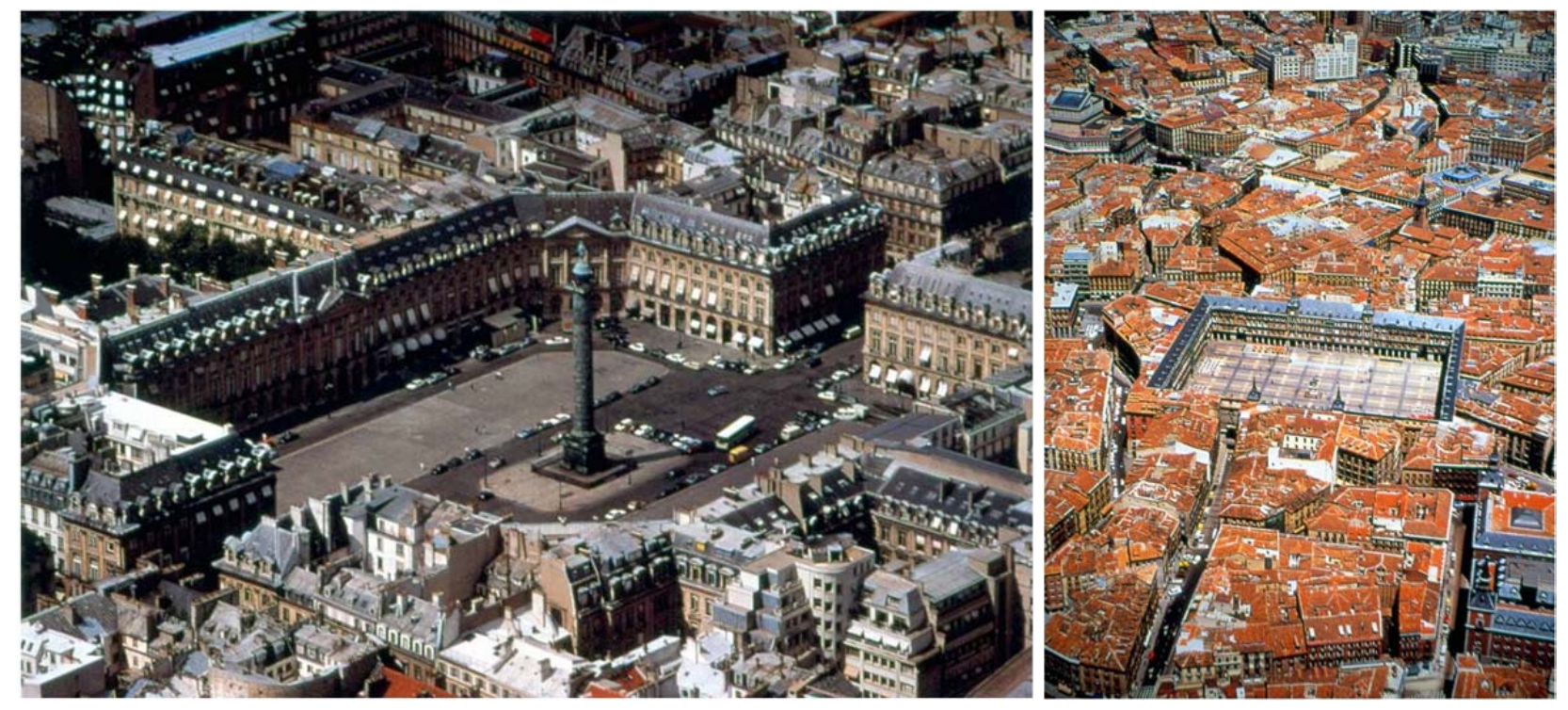

Figure 5. Place Vendôme, Paris and Plaza Mayor, Madrid (archives DUOT). 
Perhaps the most extreme case of this trend can be seen in Piazza Ducale in Vigevano. Bramante designed both the square and the buildings around it, balancing their facades with the repetition of architectural elements. But many were quite upset by the fact that the facade of the church which closed the space at the north end was not perpendicular to the square. In the late eighteenth century, the city commissioned a new facade for the church. Juan de Caramuel, a bishop and Spanish-born architect, designed a front halfmoon shaped new façade in order to complete the symmetry of Bramante square, but was careless with what would be a problematic transition into the existing church building. This obsession for control over the facade in the baroque and neoclassical traditions led us one day to make a comparison with higher-order animal species, which are, like the baroque buildings, symmetrical on the outside (we have an eye, a hand, a leg on each side) but asymmetrical on the inside (with the heart on one side, the liver on the other...). In these traditions, the position of the private interior did not matter as much as the public exterior.

The idea of the modern street appears in the early nineteenth century and features different contents. It is longer, which makes traffic congestion possible and it invites new architecture and new housing typologies, and most especially, it introduces new uses such as commerce. It is another type of street, a street which has been designed: a street with houses side by side. The London squares, which were really new forms of grouporganised residences, constituted a design precedent for the modern street. This new nineteenth century street is a new place and generates a new image. This is exemplified by Ferran Street in Barcelona, Regent's Street in London and Rue Rivoli in Paris. It has often been said that Ferran Street is a very innovative urban intervention that radically changed the way in which we understand the city and its image.

With the Modern Movement came a substantial change concerning the functional city, based on the principles of the Athens Charter, written by Le Corbusier in 1933. It is well known that these principles establish a positivist dissection of the city following four main functions: housing, work, leisure and movement. However Lewis Mumford soon realised that this approach didn't consider one essential aspect of the city: the city has always been a place of knowledge generation and cultural exchange. Such a reflection led Sert and Giedon to conduct research around civic centres and as a result, The heart of the city was published in 1952. Similar criticisms were made about the proposals contained in the Athens Charter at the end of the tenth CIAM congress, which was held in Dubrovnik in 1956. There was disagreement between the rebellious architects of Team $X$ and the orthodox architects who were loyal to Le Corbusier.

In the book The Heart of the City, Josep Lluís Sert argued that cities needed a process of recentralisation, to turn around the process of unplanned decentralisation. He also added: "When a city is replanned, it is divided into zones of different land uses [...]. Each of these areas or parts of the city needs its own centre or core, and the entire system results in a network or constellation of community centres, ranked from the smallest to the largest, with a main centre that is the expression of the city or metropolis as a whole, the centre of the city." Then, we will be able to speak of the heart of the city, which requires several essential conditions in order to exist: the separation of vehicular traffic from pedestrians, abundant vegetation, controlled trade, controlled development, a design that reflects general needs, spaces to shelter from the sun and rain, places with arcades and courtyards and a skilful and harmonious combination of high and low rise buildings. One of the proposals that was most criticised was precisely that of zoning. Critics expressed the need for a mix of uses, similar to that found in the historic city. A mix of 
uses provides better social control of the urban space and there is no need for life to be so absolutely bounded to the timing of one exclusive activity.

In the article "La segunda historia del proyecto urbano" (The second history of urban design), which was published in UR no. 5 and in the journal Lotus International in 1989, Manuel de Solà Morales expands on criticism of Le Corbusier's functional urban planning. He argues that there is another tradition in the modern architectural movement that does not create such a radical distinction between principles that are applied to urban planning and principles that are applied to architectural design. This tradition deals with the design of complex elements, in which discussions surrounding the city, the buildings, the layout of the roads, the division of land into plots, the organisation of movement and routes and the social intention of these contents are all interconnected. He describes the extent to which the application of abstract criteria to the organisation of the city and precise criteria to the organisation of architecture, leads to a major crisis: the crisis of the modern city.

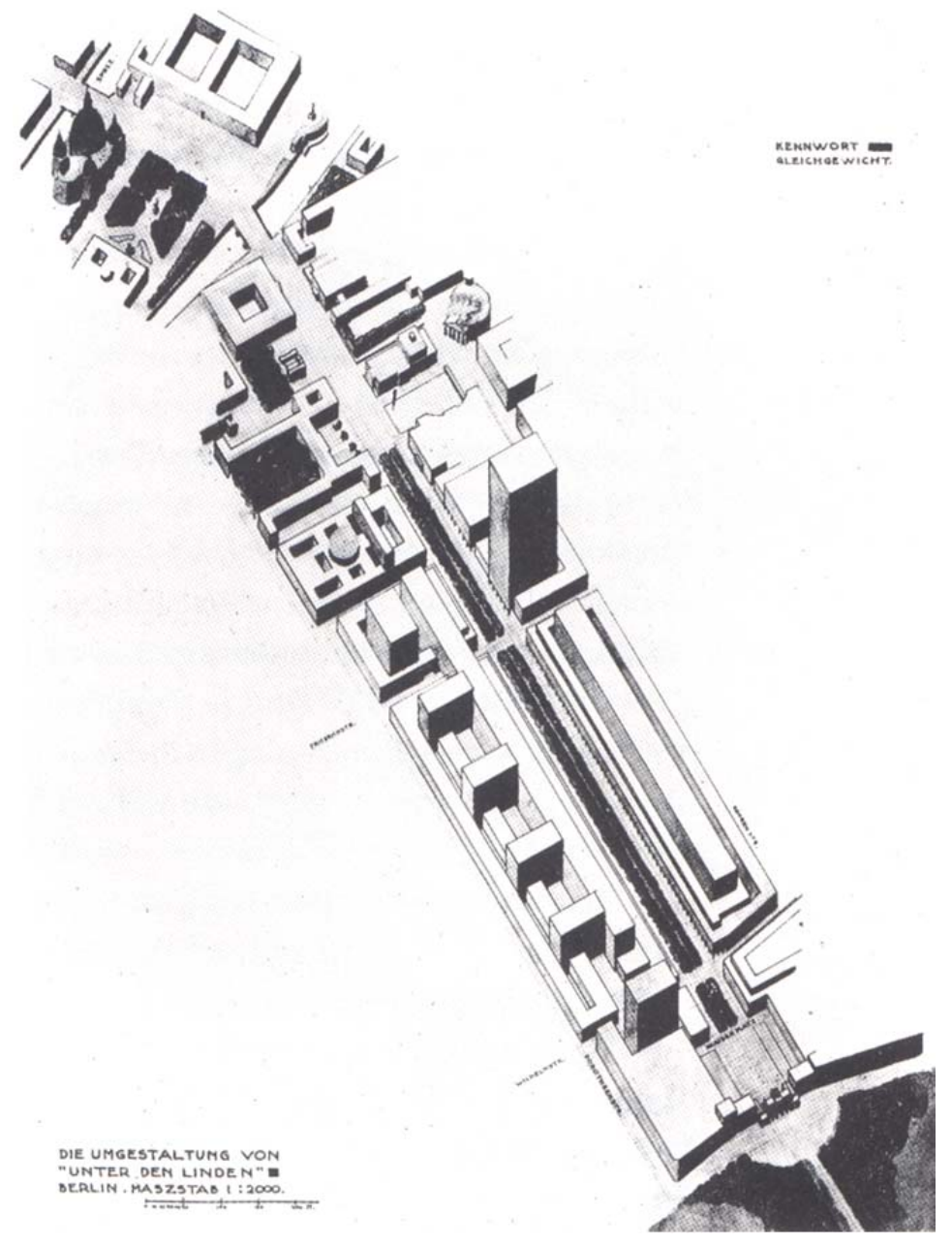

Figure 6. Unter den Linden avenue project, Berlin, by Van Eesteren $C$. (Urbanismo Revista ${ }^{\circ} 8$ ) 


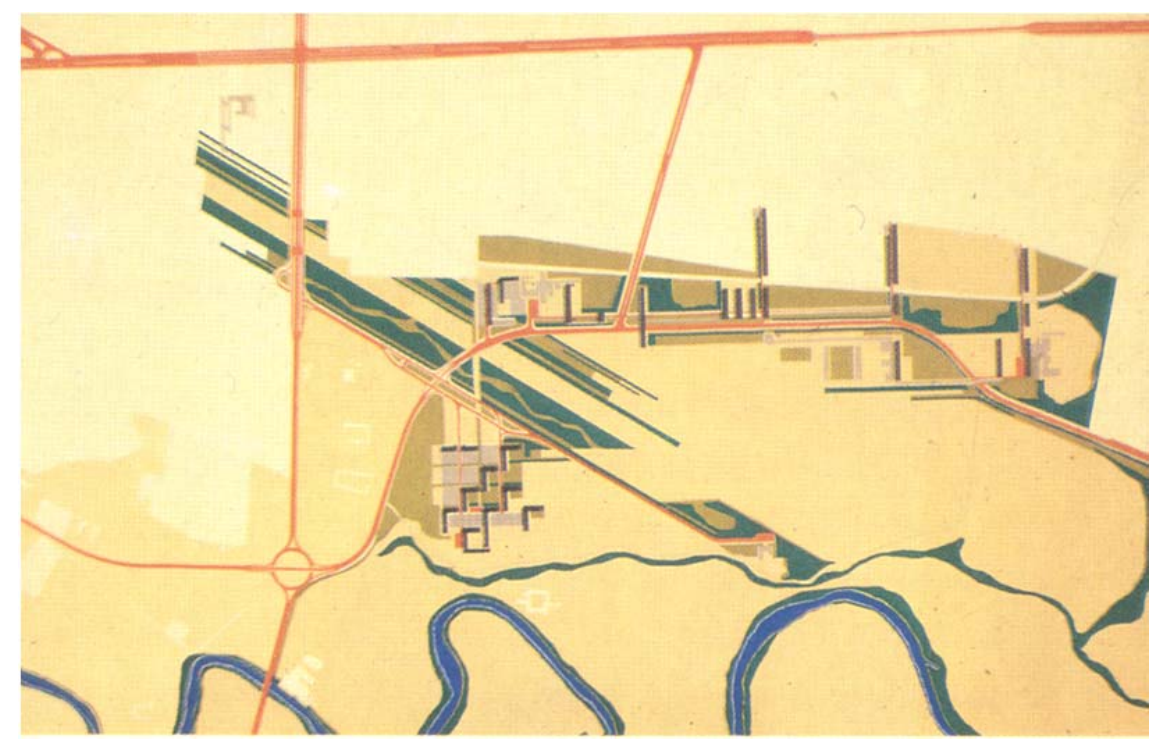

Figure 7. Planimetric detail of study for the Fiad Headquarters, Torino, by Ludovico Quaroni (Urbanismo Revista ${ }^{\circ} 7$ )

\section{On urban design for public spaces in the contemporary city}

Manuel de Solà-Morales cites Cornelis Van Eesteren, Leslie Martin and Ludovico Quaroni as examples of advocates of the modern tradition of urban design in that they share a set of commonalities, despite the fact that they approach them from different theoretical and circumstantial positions. Finally, he identifies five points that define urban designs, which are listed below:

- Territorial effects outside the area of intervention.

- Complex and interdependent contents: superseding mono-functionality (park, road, typology, etc.) and enhancing mixture of uses, users, temporal schedules and visual orientations.

- The intermediate scale, so the project can be completed within a limited time of a few years.

- Voluntarily assumed commitment to adopt an urban architecture, independently of the architecture of the buildings.

- A significant public component both in investments and in collective uses of the program.

In the opening lecture for the UPC Master's in Urban Design, entitled "Cuatro líneas, tres artículos, siete ideas: las formas de la proyectación urbanística" (Four approaches, three articles, seven ideas: forms of urban design), which took place on the 6th of March in 1995, Manuel de Solà Morales gave an extensive and reflective account of urban planning culture for the benefit of all those present. His talk made us consider the importance of urban design, with specifications as subtle as not to confuse dimension with scale. He stated that thinking about the city does not mean designing large interventions, and that the design of large interventions is frequently not about urban design. He specified that a small design is often incredibly significant for the city and that, in contrast, some enormous designs are not urban. The example he gave was the Docklands design: an impressive project in which there is no trace of reflection on what the city is.

Other compelling ideas from this unforgettable master class included the need to correctly establish the right distance or the exact measure, which is essential for 
controlling the modern city, and the concept of repetition. Frequently, when we work on planning residential areas, we are too concerned with patterns or minimum distances (for instance, to make sure that the sun reaches all parts of the development). However, we do not control the negative effect that excessive repetition of patterns and excessive distances between buildings has on space. In many modern residential districts, the profusion and disproportion of open spaces is so great that they become unsustainable spaces with no meaning, which leads to urban desertification.

Difference and diversity should be considered as enriching attributes of the city. Counterpoints or differences ensure that the city can become complex. The Eixample in Barcelona, for example, which was built on an extensive regular isotropic grid, has many different identities as each block has particular architectural features. Within this miscellany of differences it is essential to find out which of these really are of interest to the city.

We particularly appreciate the acupuncture approach to strategic design. In this approach, the general organisation of the city organism is understood in such detail that if we act on visceral or critical points, we can activate the entire organism. It's like judo strategy against the boxer. The boxer uses his own strength to throw punches but equally receives blows. On the other hand, the judoka takes advantage of his opponent's energy when he makes an "ippon".

This idea has been applied to all kinds of designs and interventions. We consider that the Grands Travaux follow this urban acupuncture approach. These were a series of works of a cultural nature that were promoted from 198I onwards by François Mitterrand, the president of France at the time, in order to democratise cultural and artistic heritage and make it accessible. They were specific interventions that put different districts of the city on the map. Such districts had been remote and forgotten until the intervention gave them a certain image or transformed them into a landmark. Projects such as the Parc de la Villette reactivated the surrounding urban fabric. The National Library of France, by Dominique Perrault, achieved the same in Tolbiac. There are many other examples. Mitterrand also applied this practice to different parts of the country: he commissioned Ciriani to design an archaeology museum in Arles and Norman Foster to design the Carré d'Art - Museum of Modern Art in Nîmes. This unprecedented and strategic creation of facilities implicitly lifted the city beyond its usual area of influence. The strategy was repeated in different French cities.

In some ways, the city of Barcelona has been adopting this strategic model, since the reestablishment of a democratic Town Council in 1979. City districts such as Nou Barris or Horta now display works by the best sculptors in the world and have architectural and urban designs of great relevance. Consequently, a cultural visit to this area is now essential. As in Paris, these interventions have implicitly reactivated the surrounding urban fabric and have put the district on the map.

Projects undertaken by Jaime Lerner are of particular importance to the acupuncture approach. He explains his experience of urban design in Curitiba in the publication Urban Acupuncture, in which he presents reflections and strategies on all scales that are a good recipe for urban interventions.

Another idea is that of collective spaces. Such spaces combine public and private ownership and uses and they are increasingly paradigmatic and of key importance to the contemporary city. According to Manuel de Solà Morales, it is essential to break the clichéd obsession with oversimplification and the differentiation between what is public and what is private. Instead, it is important to understand that the functional elements of 
transport, commercial, leisure and culture infrastructure are the modern places for social exchange between individuals and institutions.
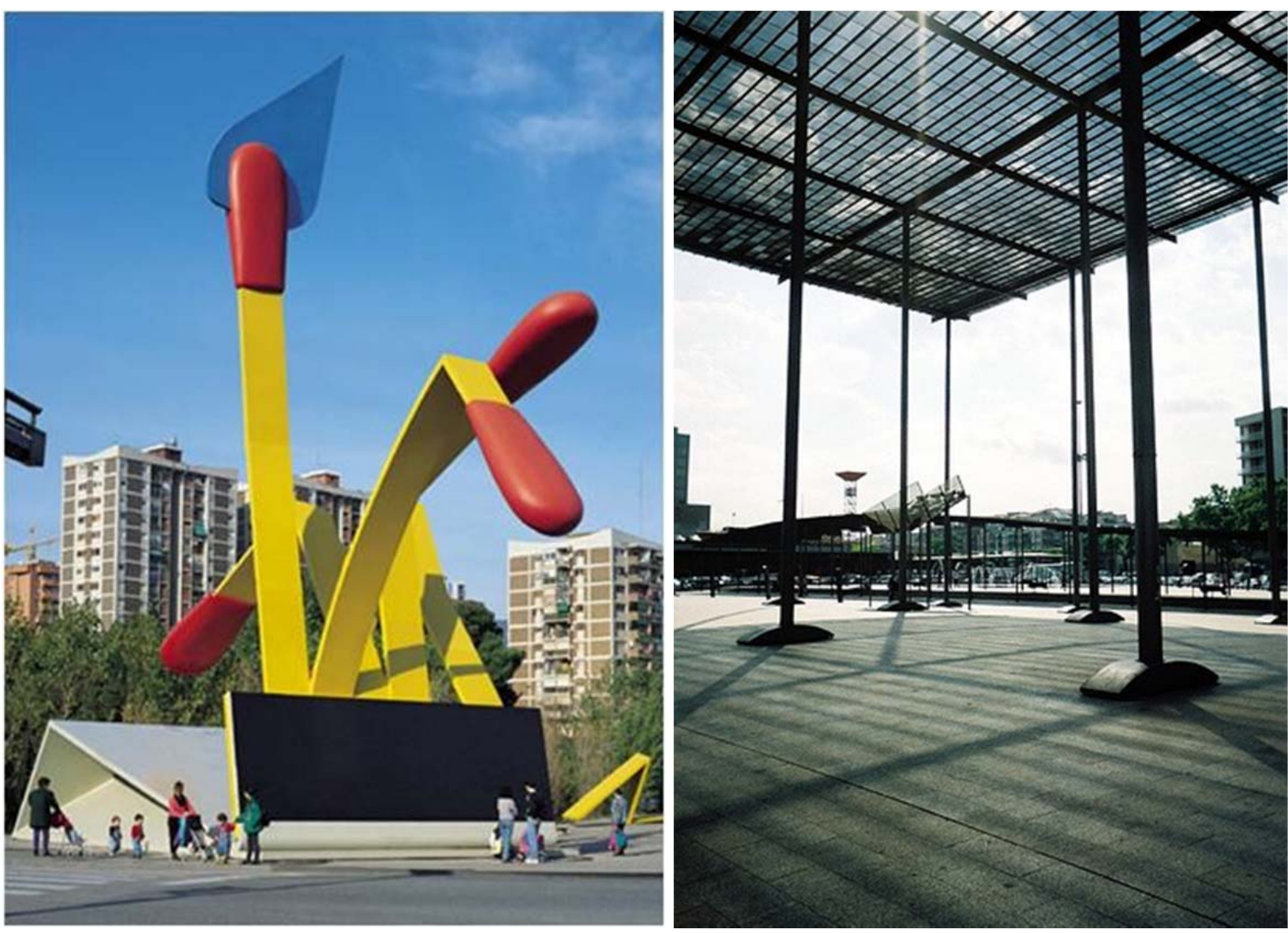

Figure 8. "Mistos", Horta-Guinardó, Barcelona, by Oldenburg C. Plaça dels Països Catalans, Barcelona, by Piñón H. i Vilaplana A. (photos by authors)

Therefore, public and private dimensions are involved in creating collective -and consequently urban- spaces.

In addition, the size of a public space is not its most important aspect. Its location and intensity are often more significant factors. Five hundred square meters in the dense Rambla of Barcelona is not the same as five hundred square meters in the Plaza de los Tres Poderes in Brasília, where enormous dimensions and an exclusive institutional use of the buildings that surround the square have lead to the desertification of an immense space in the city, most particularly when the activity that is carried out there stops. Consequently, there is no urban life in this place, which implicitly affects the safety of citizens.

\section{Towards new intense urban places}

To sum up, through urban design it is possible to contribute to the creation of real urban places, spaces or strategic points of the city that are characterised by their importance or centrality and that usually have good public transport connections. These are places for social exchange. In short, they are collective spaces or, in other words, they are intense spaces with an identity. They are linked to buildings that truly condense urban activity. 
Due to their mixture of uses, we can call many areas new centres, regardless of whether they are public or private spaces.

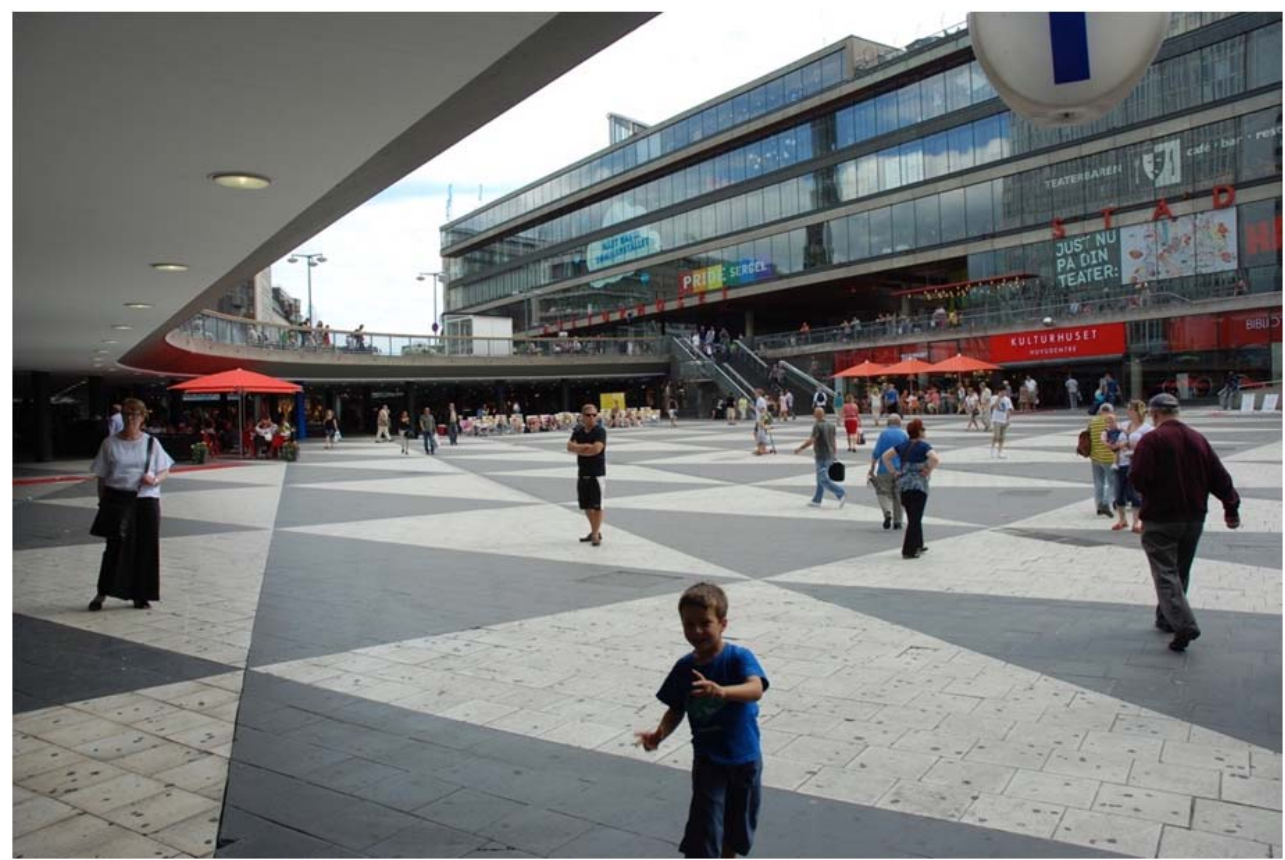

Figure 9. Sergel's Törg, Stockholm, by Sven Marvelous (photo by Laia Aguilar).

A precise definition of place could be that proposed by Joaquim Español, when he said that place is the space used by an organic society. To this reflection (developed in an unpublished text entitled The Intensive Space), he added that when we create a contemporary urban design we first have to ask ourselves the following questions: what space is the design for and for which society is it created? Is it a formalised space -an anthropological space, founder of identity, of relationships and history-that are meaningful today? If not, it only has significance as a "non-place". The design of a nonplace is an oxymoron, a contradiction in terms: the empty plots of a dispersed city are not designed, nor, basically, do leisure and transport spaces correspond to a design in the traditional sense. The design of an urban space is therefore seen as an absurdity. However, we cannot address this issue from such an antagonistic perspective. In a modern cosmopolis, the non-places of the generic city must coexist with the significant spaces of a new plural society. These are non-exclusive categories of spaces. Places and non-places, according to Joaquim Español, have to construct a complex constellation of nodes in the networks of the global city.

If we reflect on current society, we see that it is undergoing profound changes and has evolved as a result of technological progress and new labour structures. This new scenario has implicitly affected the tensions and relationships within cities, and new activities have emerged. The society of knowledge, information and communication on the one hand, and population flows on the other, mark a new horizon and a new model of the city. The need for mobility between dwellings and workplaces or between activities, which must be made sustainable by strengthening an effective public transport system, also determines the organisation of metropolises.

According to Richard Rogers, the city of the future will be compact, polycentric, sustainable, well-designed and with good transport links. This could be an effective model. 
It has some similarities with the aims of the new settlement models discussed by Peter Calthorpe in The Next American Metropolis, which involve TODs (transit-oriented developments). TODs have a commercial heart alongside a major public transport axis, which is surrounded by economic activity. In addition, dwellings are situated beside work places, so that inhabitants can walk to work or travel to another TOD using the efficient public transport system.

Thus, without categorically being defined, in recent decades cities around the world have changed substantially and the number of new urban centres has increased on the basis of good transport links.

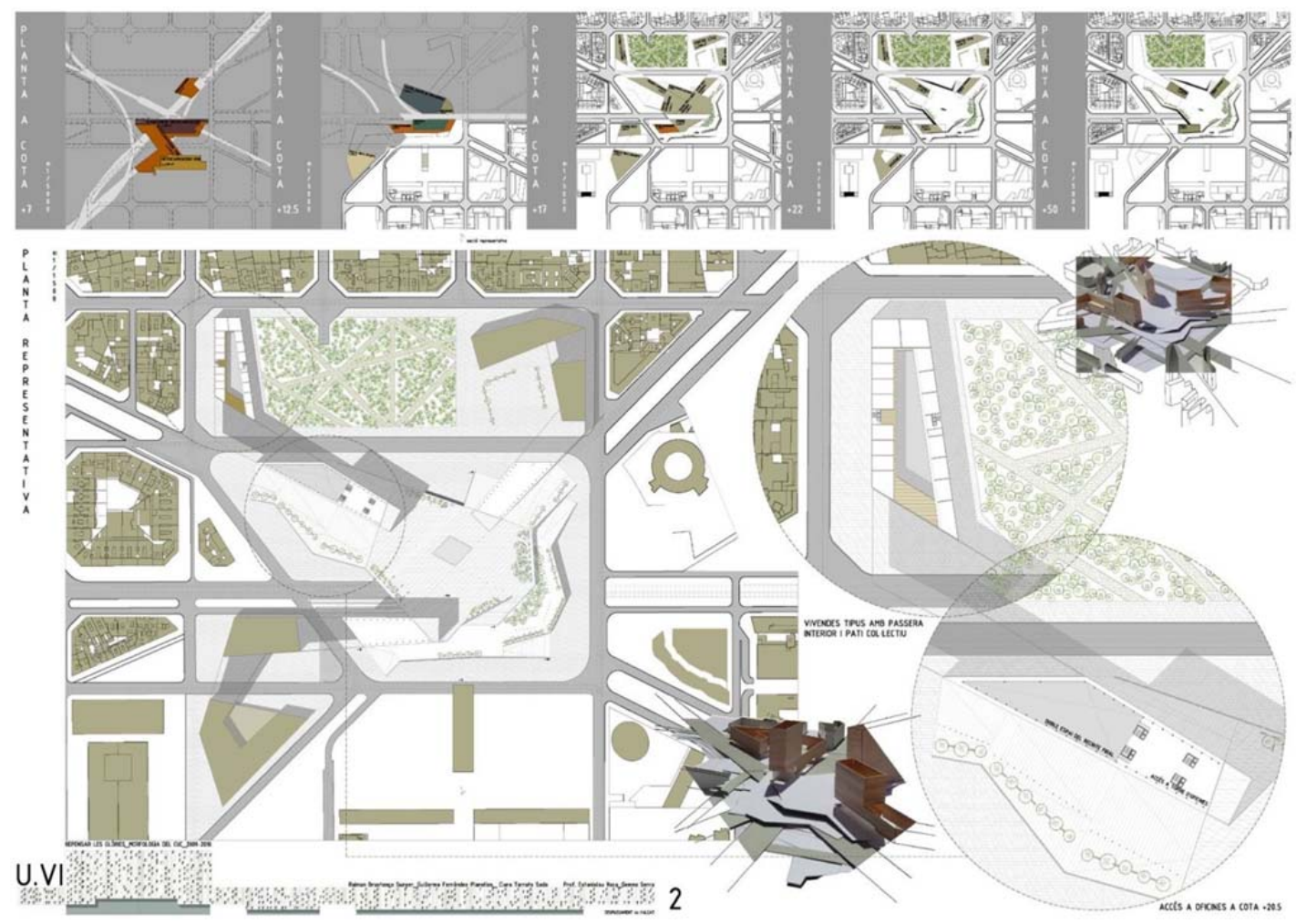

Figure 10. Example of student's work on Plaça de les Glòries, Barcelona (Clara Tarrats, Raimon Brustenga, Guillermo Fernández)

However, Collin Rowe and Fred Koetter were not so sure about the power that modern architecture potentially has to generate an urban place. In Collage City, they explain how the designs for the centre of Sant Dié or the Unité d'Habitation in Marseille by Le Corbusier differ from a fragment of a city in Tuscany. They state that they prefer the latter (which is full of complexity, identity and history), and consider that the modern city is in crisis. They suggest that the modern traditional city has not yet been established, as there are no ideal or historic references. We are not so sure. We are increasingly convinced of the force and meaning of modern architecture, which can contribute to the creation of the city when there is a commitment to urban design. We are inclined to defend the ways in which buildings may relate to each other in the contemporary world, as the protagonists and defining elements of urban space. In addition, we consider that urban architecture lies in a good architectural relationship between spaces and buildings, without which no object on its own can attempt to create city. 
The city regeneration designs that we have explored in Urbanism courses and in final degree projects in recent years at ETSAB have precisely considered areas that we have tried to transform into places with an identity and an intensity of activity: the intense urban place.

\section{References}

Calthorpe, P. (1984). The next American metropolis. MIT Press, Cambridge.

Delgado, M. (1999). El animal público: hacia una antropología de los espacios urbanos. Anagrama, Barcelona.

Español, J. (200I). El orden frágil de la arquitectura. Fundación Caja de Arquitectos, Barcelona. Lerner, J. (20I4). Urban acupuncture. Island Press, London.

Roca, E. and Martí, M. (2013) Public space: experiences, projects and management. Urbanism Research Journal, DUOT- UPC.

Rogers, R. (1998). Cities for a small planet. Faber and Faber, London.

Rowe, C. (1978). Collage City. MIT Press, Cambridge.

Sert, J. L. (1952). The heart of the city. Lund Humphrics, London.

Solà-Morales, M. (1989). “La segunda historia del proyecto urbano”. Lotus International Journal. 